\title{
MORBIDITY IN A LONDON GENERAL PRACTICE SOCIAL AND DEMOGRAPHIC DATA
}

\author{
BY \\ LILLI STEIN \\ Lecturer in Medical Statistics, Institute of Psychiatry, University of London
}

\section{INTRODUCTION}

The material presented here is part of an investigation into psychiatric and associated ill-health occurring in the general population outside hospital. The aim, in addition to methodology, was to assess the prevalence, during one year, of conspicuous psychiatric morbidity in a defined urban population, and to study possible relationships with other illness and with family and social features. These social features, and their connexion with frequency of general practitioner consultation and of illness, are presented below.

The population was defined as the patients of one group practice, and a 20 per cent. random sample was taken (for practical reasons, this was all patients whose surnames began with one of six letters of the alphabet). The risk year was March, 1956, to February, 1957, inclusive, and the period population contained all patients registered in the practice before the beginning of that year. Morbidity was considered conspicuous only if patients consulted the doctors during the risk year, and was defined in terms of the complaints and conditions presenting at those consultations. For the whole sample, data were collected retrospectively from N.H.S. cards and from practice records; further medical data for a subsample were obtained in discussions with the doctors; family and social data for two sub-sections were obtained by interviews with two different types of questionnaire, one type being asked of patients in the surgery during the summer following the risk year. For this reason the "questionnaire section" was not a representative sub-sample, being weighted by patients attending surgery and particularly by those with young children; however, the questionnaire section constitutes half the sample, and has given much useful material on social and economic features.

In the social field, the data cover age, sex, marital status, size of patient group and of family, duration of registration in the practice; occupation, duration in current job, job history; housing circumstances, duration of living in house; and relatives' medical history. In the medical field, the data cover the doctor-patient contacts for consultation purposes (routine clinic attendances were not included) during the risk year, and also during the previous year and the subsequent year; the presenting complaints at each consultation during the risk year; the previous medical history recorded; and, for a large subsample, the practitioners' assessment of the psychiatric aspects of the patients' illnesses.

\section{Population Features}

The group practice, of around 9,000 patients, is in outer S.E. London in a stable residential workingclass area. It is largely a family practice centred closely round the surgery, and is run by four doctors on the lines of a health centre; it offers many special facilities-infant welfare, toddlers' clinic, ante-natal service, visiting scheme for the elderly, and so onand keeps consistent records. The doctors were interested in the investigation and co-operative to the highest degree.

The following descriptions of the population investigated will show that, in the family and socioeconomic characteristics which might be relevant to ill-health, the people whose morbidity was studied were not an abnormal or extraordinary group. The sample contained 1,800 patients (814 males, 986 females) of whom over half had been in the practice since before 1949-an indication of the stability of the practice. Table I shows that only 9 per cent. were very recently registered (less than 9 months before the risk year).

TABle I

LENGTH OF REGISTRATION IN THE PRACTICE

\begin{tabular}{|c|c|c|c|c|}
\hline \multicolumn{4}{|c|}{ Length of Registration } & Proportion of Patients \\
\hline 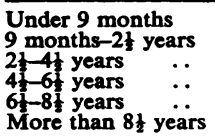 & $\begin{array}{l}\cdots \\
\cdots \\
\cdots \\
\cdots\end{array}$ & $\begin{array}{l}\cdots \\
\cdots \\
\cdots \\
\cdots\end{array}$ & $\begin{array}{l}\cdots \\
\cdots \\
\cdots \\
\cdots\end{array}$ & $\begin{array}{r}99 \\
12 \\
13 \\
13 \\
35 \\
18\end{array}$ \\
\hline All Durations .. & $\ldots$ & $\cdots$ & . & 100 \\
\hline
\end{tabular}


The sex ratio in the sample- 45 per cent. maleswas a little lower than in the Greater London conurbation or in the S.E. London "newer residential" division of the conurbation (Table II). The marital state of the men in the sample also differed from that in S.E. London; only 14 per cent. of the adult men were single, a very significantly lower proportion than in the rest of S.E. London or in Greater London. Fig. 1 and Table II show that the age composition of the sample diverged somewhat from the usual demographic pattern; children under 15 years formed nearly one-quarter of the sample. In comparison with S.E. London (which itself has a higher proportion of children than does Greater London), this excess of children and of adults aged 30-39 years was offset by an overall deficit of single men in the sample. When we remember the special facilities for babies and toddlers offered in the group practice, the excess of children and their parents is perhaps understandable.

Turning from individuals to patient groups (i.e. not households, but those members of the household who are patients of this practice), the average size
TABLE II

COMPARISON OF THE PRACTICE POPULATION WITH THE POPULATION OF SOUTH EAST LONDON (DIVISION V.D.) AND GREATER LONDON CONURBATION

\begin{tabular}{|c|c|c|c|c|}
\hline \multicolumn{2}{|c|}{ Sex and Age } & Practice & $\begin{array}{l}\text { S.E. } \\
\text { London }\end{array}$ & $\begin{array}{l}\text { Greater } \\
\text { London }\end{array}$ \\
\hline \multirow{2}{*}{ Sex Ratio } & Male & $45 \cdot 2$ & $47 \cdot 6$ & $46 \cdot 9$ \\
\hline & Female & $54 \cdot 8$ & $52 \cdot 4$ & $53 \cdot 1$ \\
\hline \multirow{2}{*}{$\begin{array}{c}\text { Proportion } \\
\text { Single Persons } \\
\text { aged } 15+\text { years }\end{array}$} & Male & $14 \cdot 4$ & $23 \cdot 6$ & $25 \cdot 4$ \\
\hline & Female & $24 \cdot 1$ & $23 \cdot 1$ & $26 \cdot 2$ \\
\hline \multirow{2}{*}{$\begin{array}{c}\text { Proportion of } \\
\text { Children under } \\
15 \text { years }\end{array}$} & Male & $26 \cdot 3$ & $22 \cdot 2$ & $21 \cdot 2$ \\
\hline & Female & $21 \cdot 2$ & $19 \cdot 2$ & $17 \cdot 9$ \\
\hline
\end{tabular}

was $2 \cdot 1$ patients per address; in the whole sample, over 40 per cent. of addresses had only one patient. However, for half the sample - the questionnaire section, where the whole household was investigated - several one-patient groups were discovered to have left the district (without removing their N.H.S. cards), and the average size of patient group was $2 \cdot 75$. In the non-questionnaire section the average size

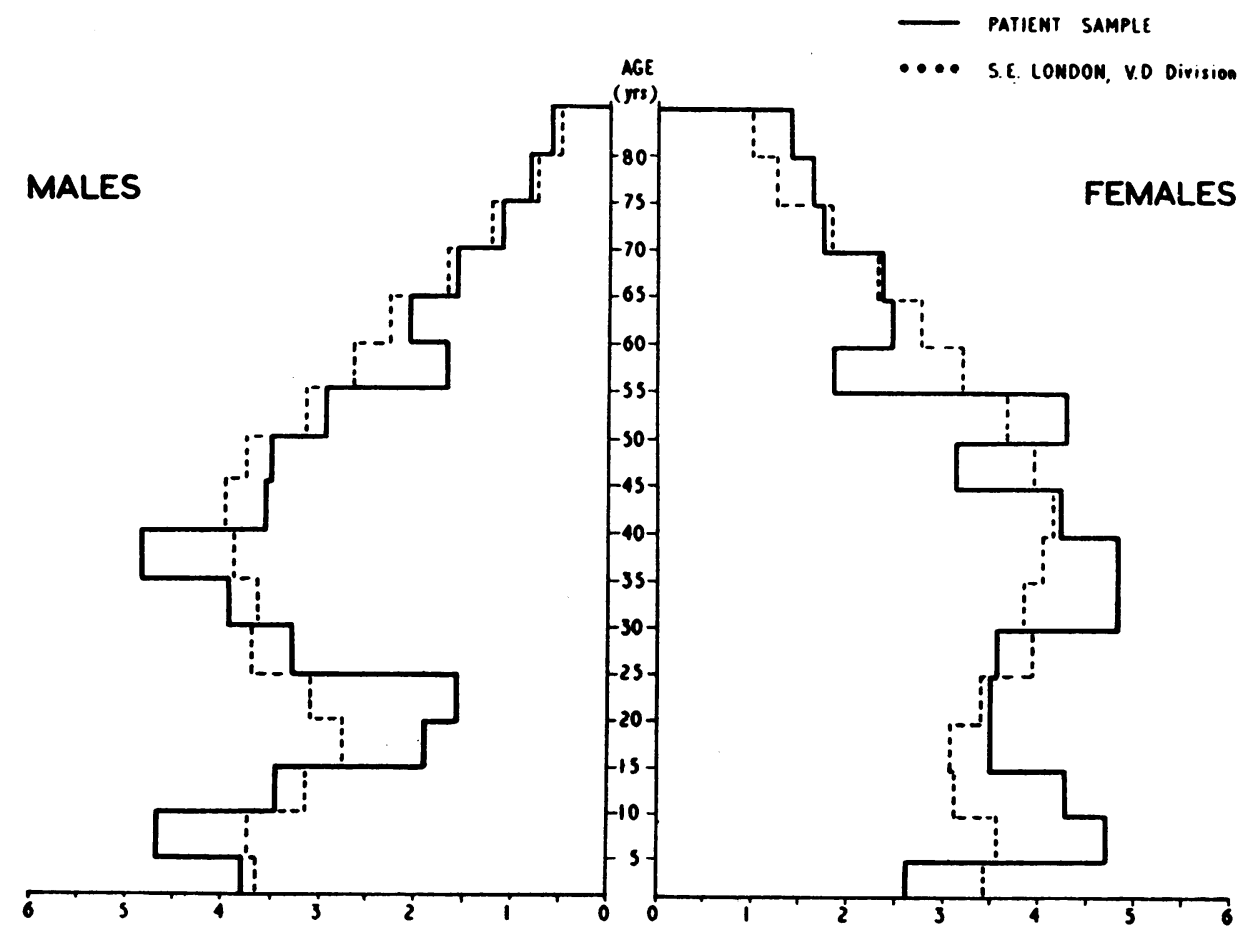

Fig. 1.-Age and sex composition of period population (1,800 patients) 
appeared to be only 1.75 patients, but it is likely that this low figure was also due to a fair proportion of the one-patient groups being in reality "dead cards".

The households in the questionnaire section yielded interesting material on practice registration. On average, there were 3.49 persons in a household, of whom 2.73 formed the "patient group", another 0.23 were practice patients but not at risk for the full year, and the remaining 0.53 persons were nonpatients of this practice. The non-patient members of these households were more commonly men than women, and the tendency for women and their children to attend the same doctor was evident; where there was only one non-patient in the household, it was more commonly an adult married man, but where there were two or more non-patients in the household they were quite commonly women and children.

The questionnaire households were, on average, slightly larger than those in England and Wales (see Table III), and a higher proportion-59 per cent.contained children under 16 years; indeed, $12 \cdot 5$ per cent. of the questionnaire households had three or more children under 16 years, as compared with the national average of 8 per cent. (However, this is not representative of the whole sample, for the nonquestionnaire section had a considerably lower proportion of children.) An indication of the stability of the families is given by the length of time

TABLE III

PERCENTAGE DISTRIBUTIONS OF HOUSEHOLD FEATURES QUESTIONNAIRE SECTION ONLY

\begin{tabular}{|c|c|c|c|c|}
\hline \multicolumn{3}{|c|}{ Household Features } & $\begin{array}{l}\text { Questionnaire } \\
\text { Households }\end{array}$ & $\begin{array}{l}\text { Great Britain } \\
1 \text { per cent. }\end{array}$ \\
\hline \multirow{3}{*}{$\begin{array}{l}\text { No. of } \\
\text { Persons } \\
\text { in Household }\end{array}$} & $\begin{array}{cc}1 & \ldots \\
2 & \cdots \\
3 & \ldots \\
4 & \cdots \\
5 & \ddot{6} \\
6 & \text { or } \text { More }\end{array}$ & $\begin{array}{l}\ddot{*} \\
\ddot{*} \\
\ddot{*} \\
\cdots\end{array}$ & $\begin{array}{r}7 \cdot 8 \\
20 \cdot 4 \\
26 \cdot 5 \\
24 \cdot 3 \\
12 \cdot 3 \\
8 \cdot 7\end{array}$ & $\begin{array}{r}10 \cdot 8 \\
27.6 \\
24 \cdot 8 \\
19 \cdot 1 \\
9.6 \\
8 \cdot 2\end{array}$ \\
\hline & \multicolumn{2}{|c|}{ All Households } & $100 \cdot 0$ & $100 \cdot 0$ \\
\hline & \multicolumn{2}{|c|}{$\begin{array}{l}\text { Average Number } \\
\text { in Household }\end{array}$} & $3 \cdot 49$ & $3 \cdot 16$ \\
\hline \multirow[t]{2}{*}{$\begin{array}{l}\text { No. of } \\
\text { Children } \\
\text { under } \\
16 \text { years }\end{array}$} & $\begin{array}{l}\text { None } \ldots \\
1 \\
2 \\
3 \text { and } 4 \\
5 \text { or More }\end{array}$ & $\begin{array}{l}\cdots \\
\ddot{*} \\
\ddot{*}\end{array}$ & $\begin{array}{r}41 \cdot 1 \\
28 \cdot 2 \\
18 \cdot 1 \\
10 \cdot 7 \\
1 \cdot 9\end{array}$ & $\begin{array}{r}56 \cdot 8 \\
21 \cdot 3 \\
13 \cdot 8 \\
7 \cdot 0 \\
1 \cdot 1\end{array}$ \\
\hline & \multicolumn{2}{|c|}{ All Households } & $100 \cdot 0$ & $100 \cdot 0$ \\
\hline \multirow[t]{2}{*}{$\begin{array}{c}\text { Duration of } \\
\text { Residence in } \\
\text { Present } \\
\text { House (yrs) }\end{array}$} & $\begin{array}{l}\text { Less than } 2 \\
2-4 \quad \ldots \\
5-9 \quad \ldots \\
10-14 \quad \therefore \\
15 \text { or More }\end{array}$ & $\begin{array}{l}\cdots \\
\cdots \\
\cdots \\
\cdots\end{array}$ & $\begin{array}{l}10 \\
27 \\
21 \\
17 \\
25\end{array}$ & E \\
\hline & \multicolumn{2}{|c|}{ All Households } & 100 & - \\
\hline
\end{tabular}

they have lived in the district; as shown in Table III, 42 per cent. of the families had lived in the sarre house for 10 years or longer. Only one-tenth had lived in their present house for less than 2 years, and of these the great majority had lived in another house in the district or had worked in the district for a considerable time. Altogether, less than 2 per cent. of the families in the questionnaire section had migrated into the district during the last 2 years.

The economic status of these households, summarized in Table IV, was fairly similar to that found in England and Wales as a whole. Among the occupied men in the questionnaire households there was some excess of men in Social Class III and some deficit of men in Social Class IV and V occupations, as compared with S.E. London or with England and Wales, and this slight difference was fairly consistent in all age groups. Similarly, considering heads of households only, the questionnaire households had some excess of Social Class III heads and some deficit of Social Classes IV and V as compared with

TABLE IV

PERCENTAGE DISTRIBUTIONS OF SOCIAL FEATURES QUESTIONNAIRE SECTION ONLY

\begin{tabular}{|c|c|c|c|c|c|}
\hline \multicolumn{3}{|c|}{ Social Features } & $\begin{array}{l}\text { Question- } \\
\text { naire }\end{array}$ & $\begin{array}{c}\text { S.E. } \\
\text { London }\end{array}$ & $\begin{array}{c}\text { Great } \\
\text { Britain }\end{array}$ \\
\hline \multirow[t]{2}{*}{$\begin{array}{c}\text { Social } \\
\text { Class of } \\
\text { Occupied } \\
\text { Males }\end{array}$} & $\begin{array}{lll}\operatorname{III}_{\text {II }} & \cdots & \text {. } \\
\text { IV } & \ldots & \\
\text { : } & & \text {. }\end{array}$ & $\begin{array}{l}\ldots \\
\cdots \\
\cdots \\
.\end{array}$ & $\begin{array}{r}4 \cdot 4 \\
15 \cdot 0 \\
65 \cdot 0 \\
7.4 \\
8 \cdot 2\end{array}$ & $\begin{array}{r}4.4 \\
16.2 \\
57.4 \\
9.5 \\
12.5 \\
\end{array}$ & $\begin{array}{r}3.2 \\
14.3 \\
53.4 \\
16.2 \\
12.9\end{array}$ \\
\hline & All Classes & .. & $100 \cdot 0$ & $100 \cdot 0$ & $100 \cdot 0$ \\
\hline \multirow[t]{2}{*}{$\begin{array}{c}\text { Social } \\
\text { Class of } \\
\text { Heads of } \\
\text { House- } \\
\text { holds }\end{array}$} & $\begin{array}{lll}{ }_{I I}^{I} & \cdots & \\
\text { III } & \ldots & \\
\text { IV } & \ldots & \\
\mathbf{V} & \cdots & \\
\end{array}$ & $\begin{array}{l}\cdots \\
\cdots \\
\cdots \\
\cdots\end{array}$ & $\begin{array}{r}2 \cdot 3 \\
16 \cdot 3 \\
6 \cdot .8 \\
9 \cdot 3 \\
8 \cdot 3 \\
\end{array}$ & $\begin{array}{l}\bar{z} \\
\bar{z}\end{array}$ & $\begin{array}{r}3 \cdot 3 \\
18 \cdot 3 \\
49.6 \\
16 \cdot 4 \\
12 \cdot 4 \\
\end{array}$ \\
\hline & $\begin{array}{r}\text { All Heads } \\
\text { Hou }\end{array}$ & & $100 \cdot 0$ & - & $100 \cdot 0$ \\
\hline \multirow{3}{*}{$\begin{array}{c}\text { No. of } \\
\text { Earners } \\
\text { in } \\
\text { House- } \\
\text { hold }\end{array}$} & $\begin{array}{l}\text { None } \\
1 \quad \ldots \\
2 \quad . \\
3 \text { or }\end{array}$ & $\begin{array}{l}\cdots \\
\cdots \\
\cdots\end{array}$ & $\begin{array}{r}8 \cdot 3 \\
44 \cdot 2 \\
33 \cdot 9 \\
13 \cdot 6 \\
\end{array}$ & 三 & $\begin{array}{r}7 \cdot 4 \\
49.8 \\
28 \cdot 7 \\
14 \cdot 1 \\
\end{array}$ \\
\hline & All Earners & .. & $100 \cdot 0$ & - & $100 \cdot 0$ \\
\hline & $\begin{array}{l}\text { Mean Ratio } \\
\text { ers to Per } \\
\text { Each Ho }\end{array}$ & & 0.44 & - & 0.45 \\
\hline \multirow{2}{*}{$\begin{array}{c}\text { Duration } \\
\text { in } \\
\text { Present } \\
\text { Job of } \\
\text { Occupied } \\
\text { Men } \\
\text { (yrs) }\end{array}$} & $\begin{array}{l}\text { Less than } 1 \\
1-2 . . \\
3-8 . \\
9-14 \\
15 \text { or More }\end{array}$ & $\begin{array}{l}. \\
\cdots \\
\cdots \\
\cdots\end{array}$ & $\begin{array}{r}9 \\
20 \\
31 \\
22 \\
18 \\
\end{array}$ & $\begin{array}{l}\bar{z} \\
\bar{z}\end{array}$ & $\begin{array}{l}= \\
\bar{z}\end{array}$ \\
\hline & All Occupie & & 100 & 一 & - \\
\hline \multirow{2}{*}{$\begin{array}{c}\text { Employ- } \\
\text { ment } \\
\text { Status of } \\
\text { Married } \\
\text { Women } \\
\text { aged } \\
15-59\end{array}$} & $\begin{array}{l}\text { Housewives } \\
\text { Employed p } \\
\text { Employed f }\end{array}$ & $\begin{array}{l}. . \\
\text { time } \\
\text { ime }\end{array}$ & $\begin{array}{l}59 \\
19 \\
22 \\
\end{array}$ & - & - \\
\hline & All Married & men & 100 & - & - \\
\hline
\end{tabular}


the 1 per cent. sample of England and Wales; when examined by household size, however, it was noted that this divergence occurred mainly in the larger households, whereas in small households the social class distribution of the heads closely resembled that in households of similar size in England and Wales.

Examining another aspect of economic statusthe proportion of earners among the members of each household-in the questionnaire households, the "earners to persons" ratio averaged 0.44 , closely similar to the England and Wales average. For each size of household, too, this similarity was consistent, the ratio being lowest for one-person households, highest of all in two-person households, and thereafter declining progressively as household size increased; though large households had more adult earners they also had greater numbers of children and elderly dependants.

These earners were, of course, mainly men, and their relative stability is indicated by the duration of their current job. Only 9 per cent. of the occupied men had been in their present job for less than one year, whereas nearly one-fifth had been in the same job for 15 years or longer-and this latter group included men in their early thirties as well as older men. Among the women, the single women were mostly in full-time jobs. The married women were mostly housewives, and those who did have employment outside their homes were as commonly in parttime as in full-time jobs. It might be noted that, when the married women had young children under school age, very few indeed were either in full-time (4 per cent.) or in part-time (10 per cent.) jobs.

One other interesting family feature, relatives' medical history, is worth reporting here. In a small group of 92 randomly-selected households, a special retrospective-history questionnaire was asked; this included questions on the past domestic and medical history of the family and relatives, and was aimed at eliciting information about psychiatric illness. Often the housewife knew nothing about her husband's family and little about her own second-degree relatives, so the information is by no means complete. Even so, over one-third of the families gave a definite history of psychiatric illness, almost always among first-degree relatives; in most cases the history was one of admission to a mental hospital, in a few it was one of mental deficiency or of illness at home with a definite diagnosis. Another one-fifth of the families gave a doubtful history, such as "nervous breakdown". Less than half the families had no history whatever; and, in a few of these, we know from practice records that there was in fact a history of mental illness, presumably suppressed at the interview.

\section{FREQUeNCY OF ATtENDANCE AND IllnesS}

Having shown briefly that the patients in the practice sample were not a peculiar or abnormal population but were ordinary families, slightly larger than the national average, and in most ascertainable social features fairly similar to the people in S.E. London, it is proposed to outline several morbidity features and to show that, from the medical standpoint also, this sample was by no means abnormal. Three aspects of frequency are presented below-the proportion who attended the practitioners during the year, the number of times they attended, and the number of illness-episodes experienced by the adults-and in all three aspects the practice sample was fairly typical of attendance as found in other investigations.

An attender was defined as a patient having a consultation for medical purposes. An episode of illness was defined in terms of the patient's presenting complaint at consultation, and if the same complaint was made at further consultations this was counted as one illness-episode. Table $\mathrm{V}$ shows that, of the whole sample, over 70 per cent. were attenders at some time in the year; for children, the percentage was much higher and was similar for boys and girls, but for adults the percentage of attenders among men was significantly lower than among women. The number of consultations per attender averaged 5.6; among child attenders, the boys' average was much higher than the girls', but among adults the men attending had a lower average than the women. The illness-episodes occasioning these attendances (analysed only for adults) averaged $2 \cdot 4$ per adult attender, and an illness caused on average $2 \cdot 5$ consultations; it may be of interest to note that more than one-third of adult attenders had only

TABLE V

ATTENDANCES AND ILLNESSES, BY AGE AND SEX

\begin{tabular}{|c|c|c|c|c|c|}
\hline \multirow{2}{*}{$\begin{array}{llll}\text { Age (yrs) } & \ldots & \ldots \\
\text { Sex } & \ldots & \ldots & \ldots\end{array}$} & \multicolumn{2}{|c|}{$<15$} & \multicolumn{2}{|c|}{$15+$} & \multirow{2}{*}{$\begin{array}{c}\text { Total } \\
\text { Practice }\end{array}$} \\
\hline & Male & Female & Male & Female & \\
\hline $\begin{array}{l}\text { Proportion of Atten- } \\
\text { ders (per cent.) }\end{array}$ & 78 & 80 & 65 & 75 & 72 \\
\hline $\begin{array}{c}\text { Consultations per } \\
\text { Attender } \quad \ldots\end{array}$ & $5 \cdot 5$ & $4 \cdot 4$ & $5 \cdot 6$ & $6 \cdot 1$ & $5 \cdot 6$ \\
\hline $\begin{array}{c}\text { Illnesses per Adult } \\
\text { Attender }\end{array}$ & - & - & $2 \cdot 2$ & $2 \cdot 6$ & $2 \cdot 4$ \\
\hline $\begin{array}{cc}\text { Consultations per } \\
\text { Adult Illness }\end{array}$ & - & - & $2 \cdot 6$ & $2 \cdot 4$ & $2 \cdot 5$ \\
\hline
\end{tabular}


one illness-episode during the year. Combining both sexes and all ages, the patient sample had an overall average of 3.9 consultations per registered patient on the list, a figure in the middle of the range found in other general practice studies.
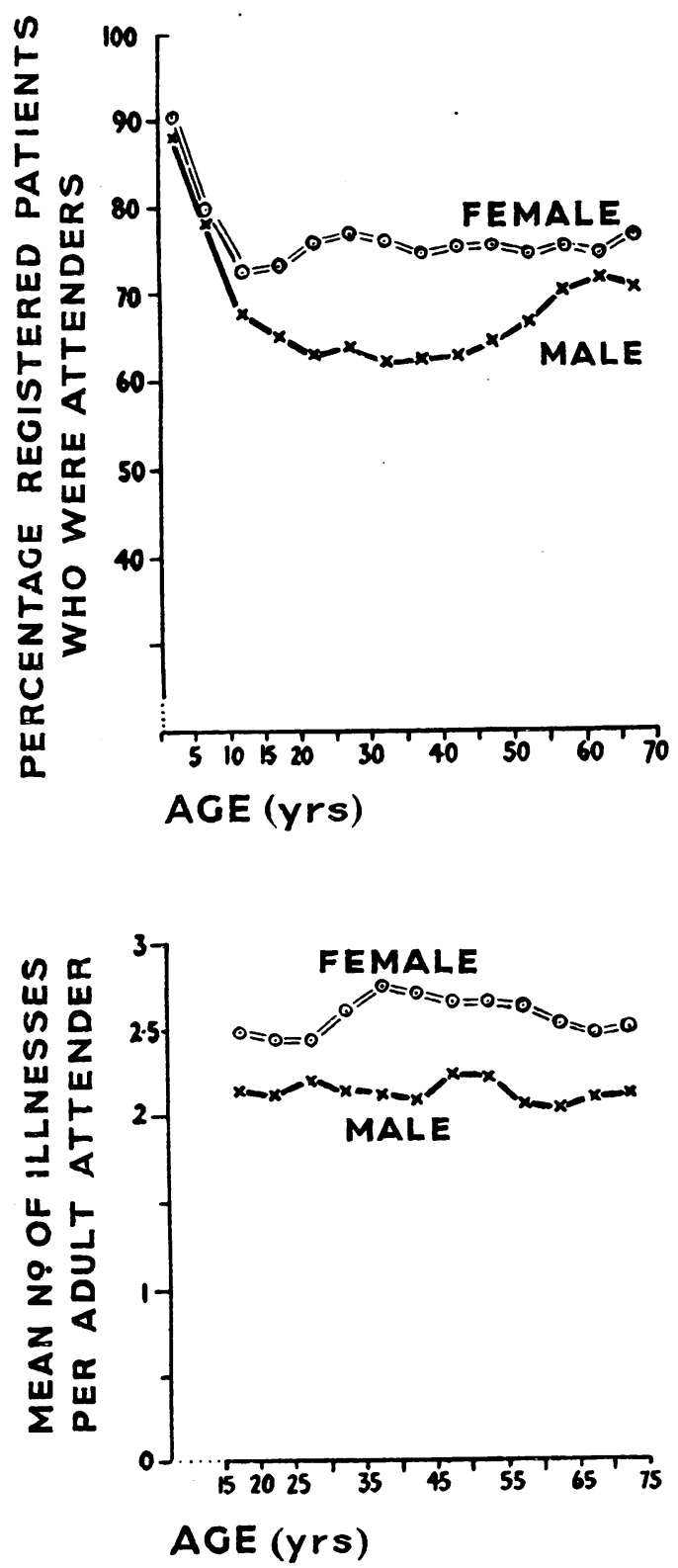

Fig. 2 shows that the percentage of attenders was high among young children. Among adult age groups there was no increase with age in the percentage who attended, except perhaps for men from age 45 years onwards, nor did increasing age bring
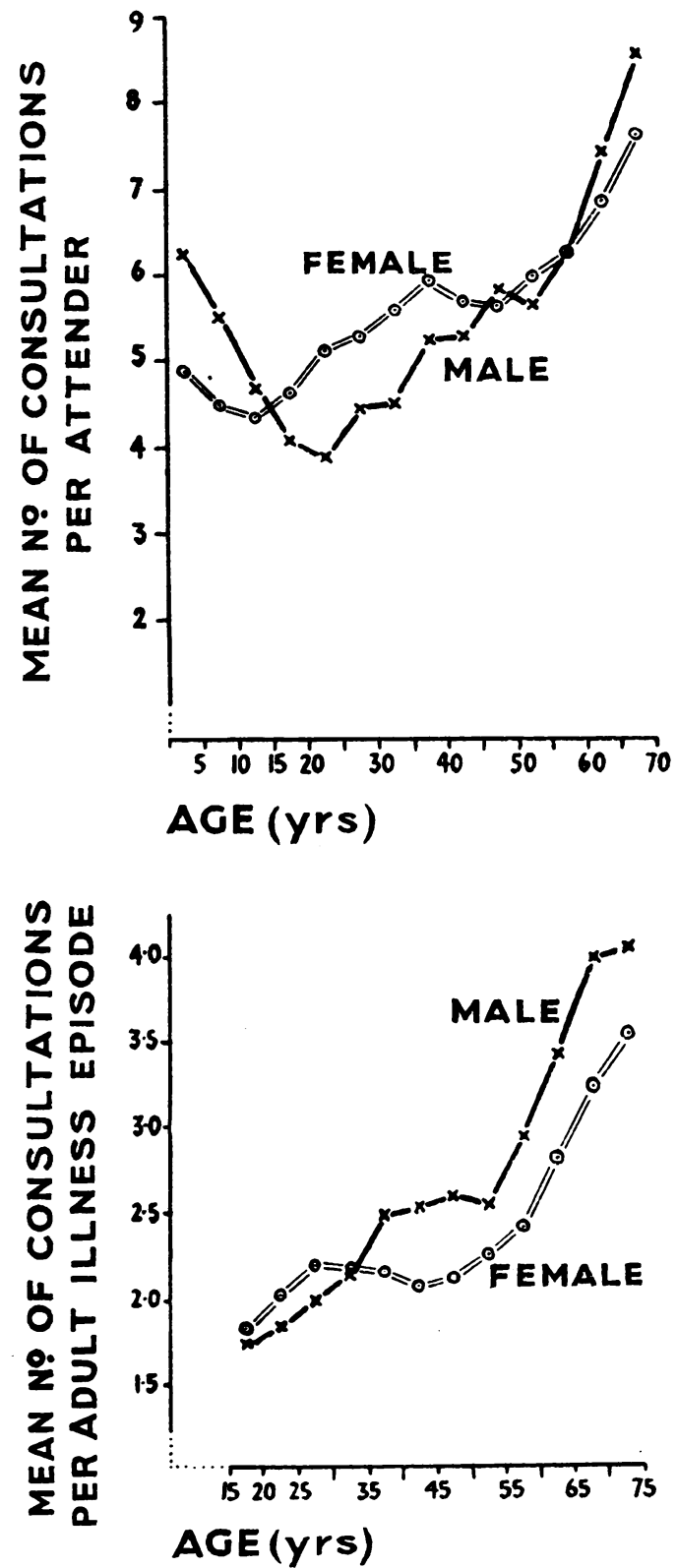

Fig. 2.-Percentage attending, frequency of consultation, and number of adult illness episodes, by age and sex. 
with it an increasing number of illness-episodes. There was, however, a consistent increase with age in the consultations per adult attender, and this was reflected in the increase with age in consultations per illness.

Regarding length of time in the practice, the percentage of attenders tended to decrease, but the consultations per attending adult tended to increase, with increasing length of registration. Regarding size of patient group, the percentage of attenders was very similar in all sizes of group except those of one patient only, where, possibly because of "dead cards", it was somewhat lower. It is of interest to note that, in patient groups of two or more 92 per cent. had at least one attender; that is to say, the practitioners had had some contact with the group during the year.

Occupational social class of the men showed no definite association with any aspect of frequency; the percentage of attenders and the mean consultations per attender in Social Classes IV and V were perhaps a little higher than in Social Classes I, II, or III, but not significantly so. Job-duration for men under 45 years old, however, revealed that those who had been in their jobs for "short" (less than 3 years) or "intermediate" times (3-9 years) had significantly higher percentages of attenders than those who had held their jobs for 9 years or more. (This excess in the proportion of attenders was not due to the age composition of the "short" and "intermediate" job-duration groups; nor did those men who attended have a higher frequency of consultations than the attenders in the "long" job-duration groups.)

For the women, neither marital state nor child status nor employment showed strong connexions with attendance. Married and single women had a similar percentage of attenders and single women a slightly lower average of consultations per attender. Among the married, those in part-time jobs had a slightly lower percentage of attenders but more complaints per attender than either housewives or those employed full-time; and the oft-stated belief that "housewives bother the doctor more because they have more time" was certainly not borne out by our sample, for the housewives had a slightly lower average of consultations per attender than those employed full-time or part-time.

Of those at risk for the previous year as well as the risk year, 20 per cent. were 2-year non-attenders, and taking the subsequent year too, nearly 17 per cent. of those at risk were 3-year non-attenders. These may be a hard core of healthy persons. There may, of course, have been "dead cards" among this one-sixth of the sample, but there was undoubtedly a large number of live cards, ascertained from other members of their patient-group.

As there were four doctors in the group practicetwo men and two women - it is of interest to make some comparison of their patients. The most marked difference was in sex composition: for the two male doctors, 56 per cent. of their adult attenders during the risk year were men patients; for the two female doctors, only 24 per cent. of their attenders were men. One of the male doctors had a high proportion of elderly and very young men among his patients.

It was found that, just as women patients had a higher frequency of consultations per attender than men, so did the two female doctors have a higher consultation rate than the two male doctors, and this applied to their men patients as well as to their women patients. Even allowing for the age differences, there appeared to be real differences between the patients coming to each of the doctors. For example, it has already been mentioned that the female doctors had a relatively small proportion of men patients, but those that they did have were very frequent attenders. Though one cannot state the extent of self-selection of patients within the practice, these differences and much other evidence indicate that self-selection certainly occurred.

\section{CONCLUSION}

The material presented here outlines certain family and social features of the 20 per cent. sample of a London group practice, and the consultations made by the adults. In frequency of doctor-consultation and of illness, the patients in the London practice appeared similar to those of other general practices; and in family and social features the patient sample consisted of ordinary families, stable in their homes and jobs, and having social contacts in the area and relatives near-by. The psychiatric hospital rate, both out-patient and in-patient, was relatively low compared with national hospital data. Against this background there was no reason to expect either extremely low or extremely high rates of psychiatric ill-health; yet, as shown elsewhere (Shepherd, Fisher, Stein, and Kessel, 1959), high rates were in fact found, and, from the general characteristics of the patient-sample, it would appear unlikely that these were due to abnormal family or economic pressures. In the present study, no association with family characteristics such as size or occupational class, or 
with family history of mental illness, has been found; perhaps further studies may produce more positive findings.

REFERENCES

General Register Office (1956). “Census, 1951. England and Wales.
Report on Greater London and Five Other Conurbations". H.M.S.O., London.

(1956). "Census, 1951. England and Wales. Housing Report". H.M.S.O., London.

H (1956). "Census, 1951. England and Wales. Occupation Tables". H.M.S.O London.

Shepherd, M., Fisher, M., Stein, L., and Kessel, W. I. N. (1959).

Proc. roy. Soc. Med., 52, 269. 